\title{
BENCHMARKING THE SUPPLY CHAIN PERFORMANCE IN INDIAN GARMENT INDUSTRY
}

\author{
Siddharth Shankar Rai ${ }^{1}$ and Dr. Sunil Giri ${ }^{2}$ \\ ${ }^{1}$ Academic Associate, Indian Institute of Management, Kashipur, India \\ ${ }^{2}$ Associate Professor, Management Development Institute, Murshidabad, West Bengal, \\ India
}

\begin{abstract}
Measuring supply chain performance is very necessary for a company, however, it is more important to identify the proper indicators based on which the performance can be evaluated. The paper benchmarks the performance measurement metrics which has been further validated by measuring the performance of garment companies in India. The analysis provides the importance of inventory turnover (ITR) and cash to cash cycle period (CCC) in supply chain performance measurement. The study also develops a relationship between CCC and ITR especially in the garment industry by considering the Indian context.
\end{abstract}

\section{KEYWORDS}

Suppy Chain Performance, Performance measurement, Inventory turns, Days of Inventory, Cash to Cash Cycle, Garment Industry, India

\section{INTRODUCTION}

Supply chain performance measurement has emerged as a very important area of study in the past few years. Companies strive for the improvement in their supply chain to gain edge over their competitors. A good and efficient supply chain can prove its worth by lowering its costs, improving quality, increasing responsiveness and adding more value. However, it is difficult to explain whether a supply chain is performing better or not unless it is measured and compared with the same measures from other companies or time. In the past couple of years researchers have focused a lot on analyzing business performance and have proposed a handful of frameworks and models for its measurement(Kaplanand Norton, 1992; Fitzgerald et al., 1991; Heskett et al., 1994; Neely et al., 1996; Kanji,1998; Bititci et al., 2000; Epstein and Westbrook, 2001; Neely et al., 2001; Ratnatungaet al., 2004; Neely, 1999; Venkatraman and Ramanujam, 1986). It has been believed that performance measurement will improve communication, collaboration and support which will improve the organization's performance (Gunasekaran and Kobu, 2007). However, going through literature it is observed that very few studies are there in the past which have produced the systematic empirical methodology to implement performance measurement systems. Major focus of the early studies would be on providing the conceptual 
background and framework unless very recent (Bourne et al., 2000; Neely et al.,2000; Nudurupati et al., 2011; Bititci et al., 2005;Kennerley and Neely, 2003)

However, the efficiency of a measurement depends upon the identifying the right measures which could drive the supply chain success (Shah and Singh, 2001). Performance metric, its requirements and indicator from company to company and industry to industry according to its requirement (Kaplanand Norton, 1992). While designing a metric for the garment supply chain in Indian industries, it has been properly considered that what its problems and requirements are. There are three major issues which the garment supply chain in India is facing these days. Being one of the largest industries in the country it consists of many large and small players. Players who vary in their supply chain, however, most of the players have got the traditional supply chain structure which results in traditional but very crucial challenges. Main challenges faced in supply chain are related to slow inventory turnovers, long days of idle inventory, delays between revenues generated and revenues collected and long payment times. These problems slowdown the supply chain and make it less responsive.

\section{METRICS DEVELOPMENT FOR PERFORMANCE MEASUREMENT}

The metrics will take three factors into account as shown in figure 1.

1.Duration between revenues generated and revenues collected.

2.Change in the inventory levels of the firm.

3.Time taken by the firm in paying its vendors.

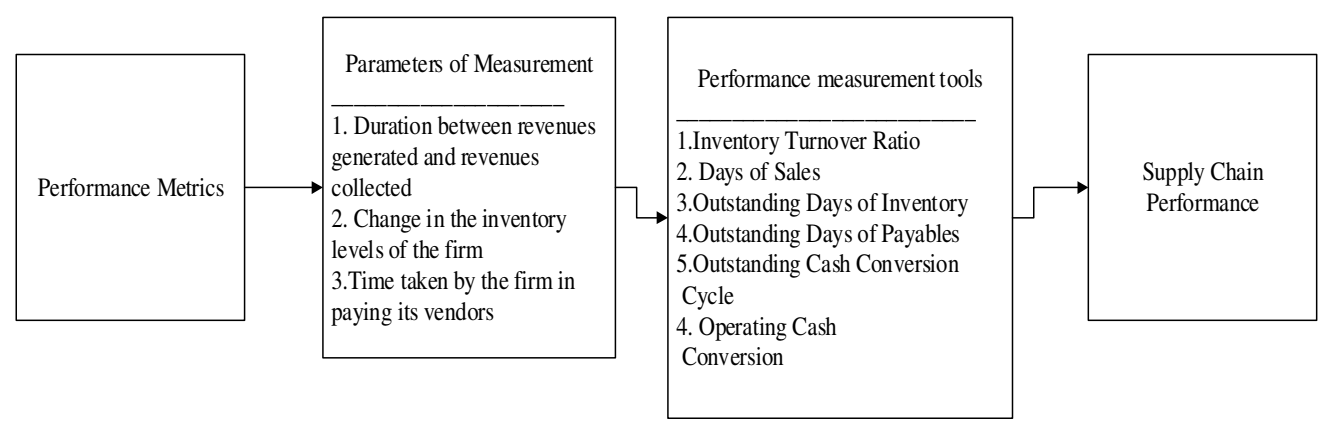

Figure 1: Measurement Framework

\subsection{Performance Measures}

Inventory Turnover Ratio:Number of times a company's inventory is sold and replaced over a period of time.

Days of Sales Outstanding: Average number of days the company takes to collect revenue after the sales is made.

Days of Inventory Outstanding:Average number of days for which the inventory is held before being sold.

Days of Payables Outstanding: Average number of days taken by a company to pay its creditors. 
International Journal of Managing Value and Supply Chains (IJMVSC) Vol. 6, No. 2, June 2015

Cash Conversion Cycle: Number of days required to convert the cash which was invested in supplies into collected cash from customers.

Operating Cash Conversion: Number of days in which cash is engaged in working capital before payment being received from the customers.

Tables 1 shows the indicators and abbreviations, which will further be used in formulating the metrics.

Table 1: Indicators in the metrics

\begin{tabular}{ll}
\hline Indicators & Abbreviations \\
\hline Inventory Turnover Ratio & ITR \\
Days of Sales Outstanding & DSO \\
Days of Inventory Outstanding & DIO \\
Days of Payables Outstanding & DPO \\
Cash Conversion Cycle & CCC \\
Operating Cash Conversion & OCC
\end{tabular}

\subsection{Metrics Formulation}

Where,

$$
\text { 1. } D S O i=\frac{A R i}{T S i} * 365
$$

$\mathrm{i}=$ time period index which is assumed here as a year or 365 days.

$\mathrm{AR}=$ Accounts receivables

$\mathrm{TS}=$ Total Sales

2. $D I O i=\frac{I n v i}{\text { COGSi }} * 365$

Where,

Inv $=$ Level of inventory during the given period of time

COGS $=$ Cost of goods sold

$$
\text { 3. } D P O i=\frac{A P i}{P i} * 365
$$

Where, 
APi $=$ Accounts Payables

$\mathrm{Pi}=$ Purchases

$$
\begin{aligned}
& \text { 4. CCC } i=D S O i+D I O i-D P O i \\
& \text { 5. OCC } i=D S O i+D I O i
\end{aligned}
$$

\subsection{Performance evaluation}

The cash cycle time consisting of days of sales, inventory and payables indicates the number of days through various processes in which it becomes able to receive its revenue. Longer are the days of sales, days of inventory and days of payables, longer will be the operating cash conversion cycle and the supply chain will be less efficient.Stewart (1995) has proposed cash to cash cycle as a useful benchmarking metric for supply chain performance measurement. Kroes\&Manikas, (2014); Garcia-Teruel and Martinez- Solano (2007) observe that shorter cash cycle time, days of sales, days of inventory and days of payables constitute better return on assets and firm performance. On the contrary, the more efficient supply chain will contain higher inventory turns and therefore, a higher inventory turnover ratio. The average inventory turnover for a manufacturing is considered around 6 and in case of retailers it considered around 12 . Therefore, in this paper we will assume the standard inventory as 6. Any company which is having inventory above 6 will be considered as a better performing company.

\section{METRIC VALIDATION WITH PRACTICAL OBSERVATION}

A secondary cross sectional data from 10 randomly selected garment manufacturing companies operating in India was taken. Major sources of the data were company documents, public documents, capitaline database and CMIE-PROWESS database. The above formulated metrics was applied on the data. Results of the analysis are shown in table 2.

Table 2: Measures of performance metrics

\begin{tabular}{lcccccc}
\hline Companies & ITR & DSO & DIO & DPO & CCC & OCC \\
\hline Company 1 & 7.0 & 58.7 & 25.7 & 13.3 & 71.1 & 84.4 \\
Company 2 & 11.5 & 32.5 & 37.9 & 14.5 & 56.0 & 70.5 \\
Company 3 & 3.9 & 213.3 & 89.5 & 42.6 & 260.1 & 302.8 \\
Company 4 & 11.0 & 103.5 & 41.7 & 83.2 & 62.0 & 145.2 \\
Company 5 & 3.0 & 21.0 & 113.8 & 208.4 & -73.6 & 134.8 \\
Company 6 & 2.7 & 23.1 & 144.1 & 159.4 & 7.9 & 167.3 \\
Company 7 & 3.8 & 140.7 & 112.8 & 93.9 & 159.6 & 253.5
\end{tabular}


International Journal of Managing Value and Supply Chains (IJMVSC) Vol. 6, No. 2, June 2015

$\begin{array}{lrrrrrr}\text { Company 8 } & 6.9 & 105.5 & 66.5 & 22.4 & 149.5 & 172.0 \\ \text { Company 9 } & 19.3 & 11.9 & 22.5 & 25.2 & 9.2 & 34.5 \\ \text { Company 10 } & 3.3 & 93.9 & 102.9 & 59.2 & 137.6 & 196.8\end{array}$

In the above analysis the highest inventory turnover is 19.3 times which has been obtained from very low CCC i.e. 9.2 days. The second highest ITR with 11.5 turns has also been obtained from a lower CCC which is 56 days. While, the bigger CCCs from companies such as company 3,7 and 8 have very low ITR as per the industry standards, and therefore, their supply chain doesn't look in a very good condition. However, there are a couple exceptions such as company 5 and company 6.5 is giving a negative CCC and very low ITR while number 6 is giving low ITR despite of a very low CCC.

Notwithstanding the two adverse results, we rely on majority of relationship observed. Eight out of 10 companies have shown that an increasing CCC will result in a decreasing ITR, while a decreasing CCC speeds up the inventory turns. In argumentative way, we can conclude that the adverse relationship in the two companies might have arisen because of the complexity in the system due to their interactions with the other factors of the external environment.

However, we cannot conclude a direct relationship between CCC and ITR that highest of one will give the lowest of other type. On the contrary, it will be more suitable to propose a varying relationship. The relationship can be explained as an increase in CCC will increase the ITR. In other words an increasing CCC is generally supposed to increase the ITR too. However, the improvement may vary from company to company. In the decreasing CCC case the ITR would also be going down to some extent which also a matter of variation from company to company. Overall, there is an inverse relationship between CCC and ITR which is subject to variation.

\section{CONCLUSION}

Cash to cash cycle time and inventory turns have been recognized as very significant methods of performance measurements of supply chain. In case of garment industry these are one of the most significant measures of measuring the supply chain as the industry is very much dependent upon the inventory turnover. It has been observed through literatures and practice that higher numbers of days of inventory, sales and payables reduce the performance of supply chain. On the other hand high inventory turns are very crucial and a good sign for any supply chain. The study tried to identify between the two of the major indicators i.e. CCC and ITR. Although, it was not a direct and linier relationship between the two, but it was also observed that both the indicators had inverse but varying relationship.

The performance metric developed here is a good measure of supply chain performance measurement. However, it can be extended by the inclusion of some primary data as well as by identifying its relationship with the other factors which affect the supply chain and its performance. 
International Journal of Managing Value and Supply Chains (IJMVSC) Vol. 6, No. 2, June 2015

\section{REFERENCES}

[1] Kaplan, R.S. and Norton, D.P. (1992), "The balanced scorecard - measures that drive performance", Harvard Business Review, January-February, pp. 71-9.

[2] Fitzgerald, L., Johnston, R., Brignall, S., Silvestro, R. and Voss, C. (1991), Performance Measurement in Service Business, CIMA, London.

[3] Heskett, J.L., Jones, T.O., Loveman, G.W., Sasser, W.E. Jr and Schlesinger, L.A. (1994), "Putting the service profit chain to work", Harvard Business Review, March-April, pp. 105-11.

[4] Neely, A. (1999), "The performance measurement revolution: why now and what Next?", International Journal of Operations \& Production Management, Vol. 19 No. 2, pp. 205-28.

[5] Neely, A., Adams, C. and Crowe, P. (2001), "The performance prism in practice", Measuring Business Excellence, Vol. 5 No. 2, pp. 6-12.

[6] Neely, A.D., Mills, J., Gregory, M., Richards, H., Platts, K. and Bourne, M. (1996), Getting the Measure of Your Business, Findlay Publications, Horton Kirby.

[7] Kanji, G.K. (1998), "Measurement of business excellence", Total Quality Management, Vol. 9

[8] No. 7, pp. 633-43.

[9] Bititci, U.S., Turner, T. and Begemann, C. (2000), "Dynamics of performance measurement systems", International Journal of Operations \& Production Management, Vol. 20 No. 6, pp. 692-704.

[10] Epstein, M.J. and Westbrook, R.A. (2001), "Linking actions to profits in strategic decision making", MIT Sloan Management Review, Spring, pp. 39-49.

[11] Ratnatunga, J., Gray, N. and Balachandran, K.R. (2004), "CEVITA: the valuation and reporting of strategic capabilities", Management Accounting Research, Vol. 15 No. 1, pp. 77-105.

[12] Venkatraman, N. and Ramanujam, V. (1986), "Measurement of business performance in strategy research: a comparison of approaches", Academy of Management Review, Vol. 11 No. 4, pp. 801-14.

[13] Gunasekaran, A. and Kobu, B. (2007), "Performance measures and metrics in logistics andsupply chain management: a review of recent literature (1995-2004) for research andapplications",International Journal of Production Research, Vol. 45 No. 12, pp. $2819-40$.

[14] Bititci, U., Cavalieri, S. and von Cieminski, G. (2005), "Implementation of performance measurement systems: private and public sectors", Production Planning and Control, Vol. 16 No. 2, pp. 99-100.

[15] Bourne, M., Mils, J., Wilcox, M., Neely, A. and Platts, K. (2000), "Designing, implementing and updating performance measurement systems", International Journal of Operations \& Production Management, Vol. 20 No. 7, pp. 754-71.

[16] Shah J, Singh N (2001), "Benchmarking internal supply chai performance: development of a framework", Journal of Supply Chain Management, Vol. 37 No.1, pp. 37-47

[17] Kroes, J. R. and Manikas, A. S. (2014), "Cash flow management and manufacturing firm financial performance: Alongitudinalperspective", International Journal of Production Economics, Vol. 148, pp. 37-50.

[18] Garcia-Teruel, P. J., Martinez-Solano, P., (2007), Effects of working capital management on SME profitability, International Journal of Managerial Finance, Vol. 3 No. 2, pp.164-177.

[19] Stewart, G., (1995), "Supply chain performance benchmarking study reveals keys to supply chain excellence", Logistics Information Management, Vol. 8 No. 2, pp. 38-44. 